\title{
Corruption and FDI Inflows: Evidence from India and China
}

\author{
Prof. Dr. Munir Hasan \\ Professor of Finance, Business School, \\ University of Kuwait, Kuwait \\ Dr. Mohd Nayyer Rahman \\ Assistant Professor, Faculty of Management, \\ Integral University, Lucknow (UP) \\ Prof.Dr. Badar Alam lqbal \\ Fulbright Scholar-in-Residence (SIR) \\ Kentucky Business School \\ Kentucky State University, Frankfurt (USA)
}

Doi: $10.2478 / \mathrm{mjss}-2018-0088$

Abstract

Foreign Direct Investment (FDI) is considered to be influenced not only by quantitative factors but also by qualitative factors. However, the present literature related to FDI focus more on quantitative factors rather than qualitative factors. One reason is that FDI is itself based on a quantitative benchmark (10\% or more investment in equity). The qualitative factors that are related to FDI are governance, democracy, human development index etc. In the present study an endeavor is made to understand that how corruption influence FDI decision. FDI is taken in terms of percentage of GDP and Corruption is represented by Corruption Perception Index. The sample period of the study is from 1995 to 2014.

Keywords: Corruption Perception Index, FDI, India, China

\section{Introduction}

Foreign Direct Investment has remained an important source of capital generation not only for developing countries but also for less developed countries. Foreign Direct Investment (FDI) is defined as investment in equity with a minimum threshold of $10 \%$ along with an aim for ownership and lasting managerial interest. More or less FDI is considered a quantitative variable as is also clear from the threshold of $10 \%$ in equity. Any quantitative value used in a definition strictly makes the variable a quantitative one. However, being a quantitative variable does not mean that qualitative factors are not important in the circular relationship. On the other hand, this also does not mean that any quantitative variable may be used for developing relationship with FDI while ignoring the theoretical considerations. A statistical relationship without a sound, logical and acceptable theoretical foundation is deemed to fall in the category of spurious relationship or instead of causal relationship, a casual relationship.

One of the important qualitative factors for which the existing literature contains theoretical relationship is Corruption (measured through corruption perception index). Corruption is considered as a political variable or a variable coming under the category of governance. Both political factors and governance, substantially affects the capital movement. Investors do not ignore such factors. The present study is an endeavor towards identifying causal relationship between FDI and Corruption for India and China. With the help of Corruption Perception Index (given by 
Transparency International) and FDI Inflows value, causal relation between FDI and Corruption would be identified. The study is divided into 6 sections. Section 1 introduces to the study and section 2 presents the conceptual framework related to FDI and Corruption. Section 3 captures the review of the existing body of knowledge. Section 4 explores the comparison of India and China in terms of FDI Inflows and Corruption. Section 5 is based on econometric models employed and econometric results, respectively. The study concludes in Section 6.

\section{Conceptual Framework}

\subsection{Foreign Direct Investment}

FDI is defined as "an investment that is made to acquire a lasting management interest (usually 10 $\%$ of voting stock) in an enterprise and operating in a country other than that of the investors" (Jhingam, 2008; World Bank, 1996; Sen, 1995). FDI has both stock and flow concept. However, in the international finance studies focus remains on flow concept as it gives a timely picture of investment in the host country. The different modes of FDI include Greenfield Investments, Mergers \& Acquisitions and Joint Ventures. The supposed to be determinants of FDI includes size of the economy, inflation, political stability, exchange rate mechanism, trade openness, economic growth etc. Overall most of the macro economic variables are considered potential determinants of FDI. The common motives of FDI include market seeking, resource seeking and efficiency seeking. The theories of FDI that explains the present and past behaviour includes Classic FDI Theory (Hymer, 1960; Kindleberger, 1969), Internalisation and Transactions Cost Theory (Buckley and Casson, 1976), Location Theory (Vernon, 1966) and Eclectic Paradigm Theory (Dunning, 1977, 1988). FDI is also related to Crowding In effect and Crowding Out effect in an economy. Surprisingly, FDI is also considered by few as a necessary evil due to the fact that a country facing low domestic investment has no option but to rely on foreign investment.

\subsection{Corruption}

Corruption is considered by all as not only morally incorrect but also an indicator of economic inequality and a negative factor from the point of view of governance. Corruption is used as a highend political issue to mobilize voters and to change the powerful regime of countries. Corruption may be both good and bad for the multi-national corporations depending on time and objective as well as certain other factors. CPI Score relates to perceptions of the degree of corruption as seen by business people and country analysts and ranges between 10 (highly clean) and 0 (highly corrupt).

\section{Review of Literature}

Developing a relationship between FDI and Corruption should first aim at a causal relationship but that is scarce in the literature. However, identifying specific impact of Corruption on FDI has gained prominence in recent years due to availability of data on corruption by Transparency International. Habib and Zurawicki (2002) stated that corruption does not seem to deter FDI in absolute terms forcing on the fact that despite corruption countries have received good FDI Inflows (e.g. China, Brazil, Mexico). Corruption can be considered as an important explanatory variable under the category of attractiveness of a location. Corruption is considered both illegal and improper by United Nations (Malta Conference, 1944). In the present times, the quantification of corruption has been in the form of corruption perception index presented by Transparency International. It has been identified that corruption is widespread in case the political leadership enjoys unrestricted and unquestioned power (Tanzi, 1998). It has also been observed that corruption prevents development of fair and efficient market conditions that are paramount for a free market economy (Boatright, 2000).

A number of studies have supported the view that there exists a negative relationship between corruption and FDI where corruption is the corruption perception index (Wei, 2000; Busse et al., 1996). On the contrary, few authors have argued that these results are not consistent by observing that no significant negative relationship was found between FDI and Corruption (Hines, 1995; 
Wheeler \& Mody, 1992). Drabek and Payne (1999) observed a negative relationship between nontransparencies (which included corruption) on FDI but here the corruption was within a composite variable. The behaviour of individual variable may differ from a composite variable. Based on three years data from a panel of 89 countries, it was concluded that corruption is serious obstacle for investment. A negative effect of corruption on FDI was found (Habib \& Zurawicki, 2002).

\section{FDI and Corruption in India and China}

India and China comes under the category of emerging economies and have shown a promising trend in their FDI Inflows. However, the condition is better captured when FDI is seen as a factor of GDP expressed in decimal as percentage of GDP. FDI as percentage of GDP is not only normal but also its exponential relationship minimize the variances. Annexure I presents the variable descriptions. Figure 1 shows the FDI trends (as percentage of GDP) for India and China. An analysis of figure 1 gives a clear impression that there is a negative correlation between FDI Inflows of India and China for the sample period of 1995 to 2014. The sample period is selected as both variables FDI and CPI are available and before 1995, CPI scores are not available. FDI Inflows of India as percentage of GDP is increasing over the period and has fallen only after 2008 and from 2010 , it has recovered but without achieving the top values of 2009. Strangely, for China, FDI as percentage of GDP has been falling from 1995 to 2014. This is in the backdrop of emerging slowdown in the economy due to which the GDP growth rate of China is decreasing. With the help of scatter plot an attempt is made to delve into the deeper relationship presented in Figure 2.

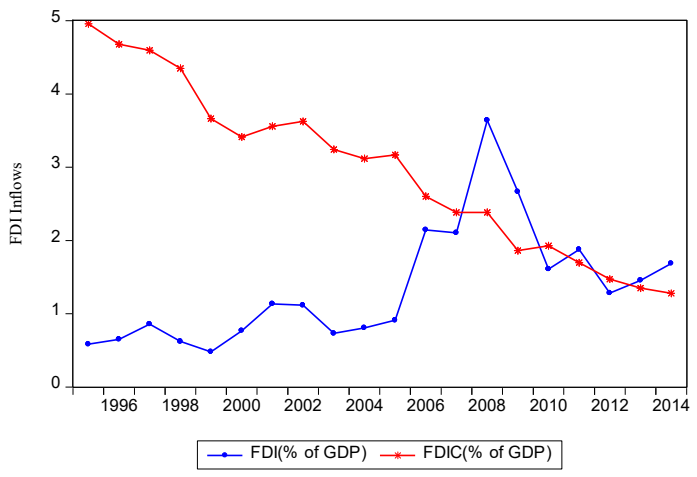

Figure 1. FDI Inflows for India and China

Source: Prepared by the author

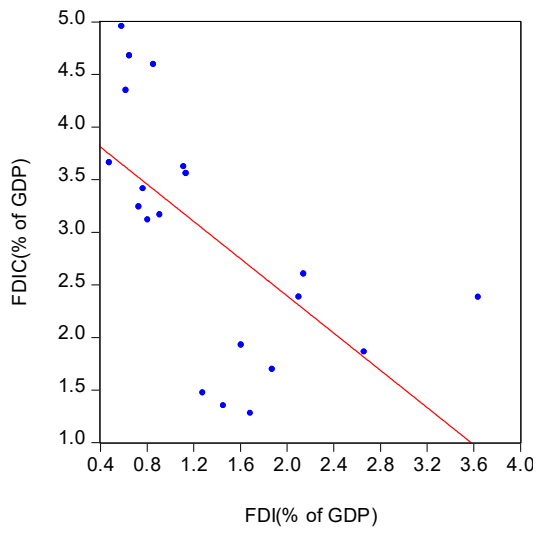

Figure 2. Scatter Plot for FDI of India and China

Source: Prepared by the author 
The scatter plot of FDI for India and China shows the scattering of the observations. A regression fitted line is also put in to identify the plausible linkages between the two series. From figure 2, it is clear that there appears to be an inverse trend between FDI of India and China.

With respect to Corruption, Corruption Perception Index $(\mathrm{CPI})$ ranking is globally very important for comparison. The lower the rank the more corrupt the nation is. In this regard, Table 1 presents the ranking of India and China. Transparency International is credited to develop this indicator but the ranking by the company is available only from 1996. Annexure II shows the data sets used in the study. Thus, no ranking is observed for 1995. For China from 1996 to 2000, the ranking has deteriorated meaning thereby that it became more corrupt. The same trend had continued from 2001 to 2005 . However, from 2006 onwards the deterioration in China on the index was much worse in the sense that in 2014 it reached to 100 and finally settled at 83 in 2015 . On the other hand, India has performed better in CPI. From 1996 to 2000, the ranking deteriorated from 46 to 69 . From 2001 to 2005 , it again deteriorated from 71 to 88 . It reached to 85 in 2014 and finally settled at 76 but never touched the figure of 100 like China.

Table 1: Ranking as per Corruption Perception Index

\begin{tabular}{|c|c|c|}
\hline Year & China & India \\
\hline 1995 & NA & NA \\
\hline 1996 & 50 & 46 \\
\hline 1997 & 41 & 45 \\
\hline 1998 & 52 & 66 \\
\hline 1999 & 58 & 72 \\
\hline 2000 & 63 & 69 \\
\hline 2001 & 57 & 71 \\
\hline 2002 & 59 & 71 \\
\hline 2003 & 66 & 83 \\
\hline 2004 & 71 & 90 \\
\hline 2005 & 78 & 88 \\
\hline 2006 & 70 & 70 \\
\hline 2007 & 72 & 72 \\
\hline 2008 & 72 & 85 \\
\hline 2009 & 79 & 84 \\
\hline 2010 & 78 & 97 \\
\hline 2011 & 75 & 95 \\
\hline 2012 & 80 & 94 \\
\hline 2013 & 80 & 94 \\
\hline 2014 & 100 & 85 \\
\hline 2015 & 83 & 76 \\
\hline
\end{tabular}

Source: Transparency International

The Corruption Perception Index scores are the raw data for the study. Figure 3 is an attempt to capture the trends in CPI scores for both India and China. The scores were previously measured on a scale of 10 by Transparency International but later on the scale was changed to the base of 100 . For the objective of symmetry, the base of 10 was selected for the scores and any data on the scale of 100 was transformed into the base of 10 . From figure 3 , it is crystal clear that the scores of both countries has an increasing trend. A low score means a high corruption and thus both India and China are witnessing increased corruption levels. Though from the figure it is clear that the level of corruption in China (CPIC) is more than India (CPI) but the margin is not large, though significant. 


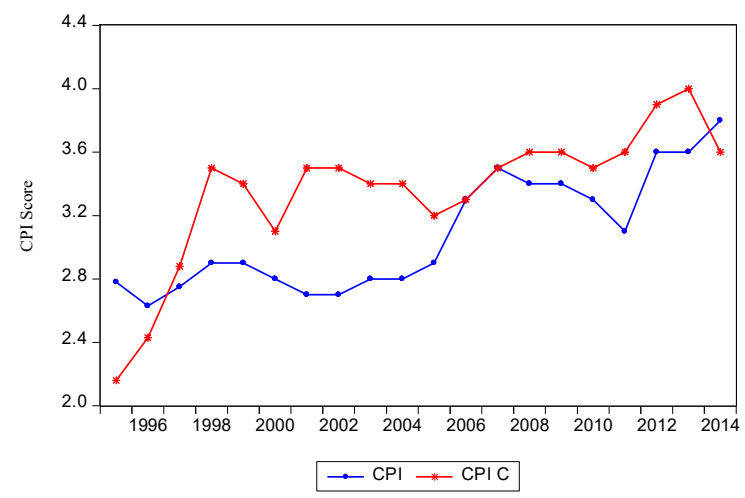

Figure 3. Corruption Perception Index of India and China

Source: Prepared by the author

Moving on to the analysis of India, a scatter plot (Figure 4) is developed for FDI and CPI scores. The observations are scattered in way that shows a direct relation between the two, that is, as the $\mathrm{CPI}$ score (CPI) increases FDI also increases. A high score means a low corruption. Thus, it supports the theory that as corruption index scores increases indicating fall in corruption, FDI also increases. The regression fitted line identifies the direct relation between both variables for India.

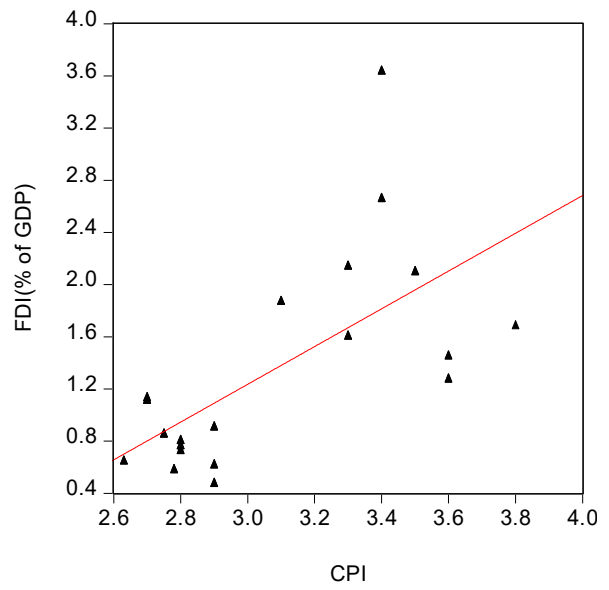

Figure 4. Scatter Plot for India

Source: Prepared by the author

On the other hand, for China there appears to be a contradiction to the theory of corruption. The scatter plot presented in Figure 5 for FDI (FDIC) and CPI (CPIC) of china shows the dispersion. However, the regression fitted line explains that there is an inverse relationship between FDI of China and CPI scores of China. Theoretically, this means that as CPI scores are increasing and FDI Inflows are decreasing in the country. The plausible reason for deviating from the theory may be some model misspecification while generating the regression fitted line. However, there also evidences is previous researches that shows that at times the relationship remains inconclusive. Also MNCs may get attracted to corrupt countries if it benefits their objectives. 


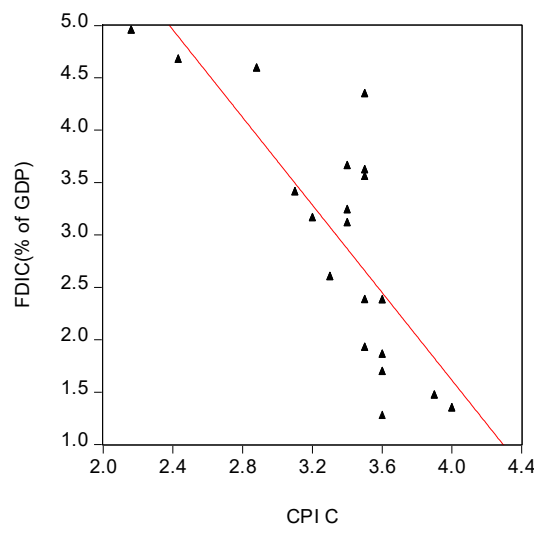

Figure 5. Scatter Plot for China

Source: Prepared by the author

Table 2highlights the cross variable correlation between bilateral variables of FDI and Corruption for both India and China. From table 2 it is clear that correlation between FDI and CPI (India) is positive with a value of 0.65 , which shows it to be moderate correlation. On the other hand, the correlation between the same variables for China is negative with a value of -0.86 . This outcome shows that theoretical foundation for India and China are different with respect to the expected signs of the parameter.

Table 2: Correlation Matrix

\begin{tabular}{|c|c|c|c|c|}
\hline & CPI & CPIC & FDI & FDIC \\
\hline CPI & 1.000000 & 0.722290 & 0.648798 & -0.863302 \\
\hline CPIC & 0.722290 & 1.000000 & 0.629146 & -0.808141 \\
\hline FDI & 0.648798 & 0.629146 & 1.000000 & -0.765414 \\
\hline FDIC & -0.863302 & -0.808141 & -0.765414 & 1.000000 \\
\hline
\end{tabular}

Source: Output generated through Eviews9.5

\section{Econometric Modelling and Estimation Results}

The present study utilities the existing body of knowledge related to applied time series econometrics and attempts to follow the deduction approach. Ordinary Least Squares regression will be the primary technique used for the study. The regression to be employed would be like a bilateral regression therefore it would assume no problem of autocorrelation or multicollinearity. The objective of parsimonious model is the reason for selecting OLS regression. The model specification is given in equation 1 .

$$
F D I_{t}=\theta_{0}+\theta_{1} C P I_{t}+\mu_{t} \ldots \text { (1) }
$$

On the other hand, the specific equations for India and China are the equations 1.1 and 1.2. Two models are developed on the basis of model specification; one for India and one for China. The expected signs of the parameters are decided on the basis of theoretical foundations as well as the scatter plot output.

$\boldsymbol{f d i}_{\boldsymbol{t}}=\boldsymbol{\beta}_{\mathbf{0}}+\boldsymbol{\beta}_{\mathbf{1}} \boldsymbol{c p i} \boldsymbol{i}_{t}+\boldsymbol{\mu}_{t} \ldots$ (1.1) [Model for India]

$\boldsymbol{f d i c}_{t}=\boldsymbol{\beta}_{0}+\boldsymbol{\beta}_{1}$ cpic $_{t}+\boldsymbol{\mu}_{t} \ldots$ (1.2) [Model for China]

The hypotheses for the study are:

$\mathrm{H}_{01}$ : There is no significant impact of corruption on FDI of India.

$\mathrm{H}_{02}$ : There is a negative impact of Corruption on FDI of India. 
$\mathrm{H}_{03}$ : There is no significant impact of corruption on FDI of China.

$\mathrm{H}_{04}$ : There is a negative impact of Corruption on FDI of China.

The output for model based on equation 1.1 is given in Table 3 . Hypothesis 1 and 3 focus on the presence of significant impact of Corruption on FDI. Corruption here is represented by Corruption Perception Index and an increase in its value from 0 means decreasing corruption. Thus, the higher the index the less corrupt the country is. Nevertheless, hypothesis 1 and 3 ignores whether the relation is inverse or direct. For identifying that, hypothesis 2 and 4 are put in. A negative sign of the parameter indicates a positive impact of corruption on FDI. On the other, a positive sign indicates a negative impact of corruption on FDI. Table 3 presents the output for accepting/ rejecting hypothesis 1 and 2 .

Table 3: OLS Output for India

\begin{tabular}{|c|c|c|c|c|}
\hline \multicolumn{4}{|c|}{ Dependent Variable: FDI } & \\
\hline Variable & Coefficient & Std. Error & t-Statistic & Prob. \\
\hline $\mathrm{CPI}$ & 1.447686 & 0.395268 & 3.662544 & $0.0018^{*}$ \\
\hline $\mathrm{C}$ & -3.108162 & 1.226789 & -2.533575 & $0.0208^{*}$ \\
\hline R-squared & 0.427011 & \multicolumn{2}{|c|}{ Mean dependent var } & 1.355055 \\
\hline F-statistic & 13.41423 & Durbir & on stat & 1.150869 \\
\hline Prob(F-statistic) & \multicolumn{4}{|c|}{$0.001781^{*}$} \\
\hline
\end{tabular}

Source: Output generated through Eviews9.5

As per the output, the model is significant having a probability value less than $0.05(0.0017)$. The probability value of intercept and coefficient also suggest that null hypothesis of "no significant impact" is rejected. Therefore, there is a significant impact of CPI on FDI for India. The parameter of corruption has a positive sign indicating that there is a negative impact of corruption on FDI for India. In other words, a higher Corruption Perception Index for India indicates higher FDI Inflows expressed as percentage of GDP. Thus, $\mathrm{H}_{01}$ is rejected while $\mathrm{H}_{02}$ is accepted. Annexure III additionally shows the actual, fitted and residual graph for the regression model based on equation 1.1. Table 4 shows the output in the same fashion for China for the sample period 1995 to 2014.

Table 4: OLS Output for China

\begin{tabular}{|c|c|c|c|c|}
\hline \multicolumn{5}{|c|}{ Dependent Variable: FDIC } \\
\hline Variable & Coefficient & Std. Error & t-Statistic & Prob. \\
\hline CPI_C & $\mathbf{- 2 . 0 8 9 5 5 5}$ & 0.379231 & -5.509982 & $\mathbf{0 . 0 0 0 0}^{*}$ \\
\hline C & $\mathbf{9 . 9 7 2 9 2 8}$ & 1.282072 & 7.778759 & $\mathbf{0 . 0 0 0 0}^{*}$ \\
\hline R-squared & 0.627791 & Mean dependent var & 2.965606 \\
\hline F-statistic & 30.35990 & Durbin-Watson stat & 0.680211 \\
\hline Prob(F-statistic) & \multicolumn{5}{|c|}{$\mathbf{0 . 0 0 0 0 3 1}^{*}$} \\
\hline
\end{tabular}

Source: Output generated through Eviews9.5

As per the output generated for model 2 , the model is significant having a probability value less than $0.05(0.0000)$. The probability value of intercept and coefficient also suggest that null hypothesis of "no significant impact" is rejected. Therefore, there is a significant impact of CPI on FDI for China. The parameter of corruption has a negative sign indicating that there is a positive impact of corruption on FDI for India. In other words, a lower Corruption Perception Index for China indicates higher FDI Inflows expressed as percentage of GDP. Thus, $\mathrm{H}_{03}$ and $\mathrm{H}_{04}$ both are rejected. Annexure III shows the actual, fitted and residual graph for the regression model based on equation 1.2. Table 5 presents the decision with respect to acceptance/ rejection of hypothesis for the study. 
Table 5: Results of Hypothesis Testing

\begin{tabular}{|c|l|c|c|c|}
\hline S.No & Hypothesis & $\begin{array}{c}\text { Expected Sign of } \\
\text { Parameter }\end{array}$ & $\begin{array}{c}\text { Actual Sign of } \\
\text { Parameter }\end{array}$ & Decision \\
\hline 1 & $\begin{array}{l}\mathrm{H}_{01}: \text { There is no significant impact of } \\
\text { corruption on FDI of India. }\end{array}$ & Not Applicable & Not Applicable & Rejected \\
\hline 2 & $\begin{array}{l}\mathrm{H}_{02}: \text { There is a negative impact of Corruption } \\
\text { on FDI of India. }\end{array}$ & $\mathbf{( + )}$ & $\mathbf{( + )}$ & Accepted \\
\hline 3 & $\begin{array}{l}\mathrm{H}_{03}: \text { There is no significant impact of } \\
\text { corruption on FDI of China. }\end{array}$ & Not Applicable & Not Applicable & Rejected \\
\hline 4 & $\begin{array}{l}\mathrm{H}_{04}: \text { There is a negative impact of Corruption } \\
\text { on FDI of China. }\end{array}$ & $\mathbf{( + )}$ & $\mathbf{( - )}$ & Rejected \\
\hline
\end{tabular}

Source: Prepared by the author

\section{Conclusion}

Corruption is an important qualitative parameter for attracting Foreign Direct Investment. The sole quantitative variable as a proxy for Corruption is Corruption Perception Index. Corruption is immoral and negative but it can have both type of relationship with Foreign Direct Investment such as attracting FDI and flying off FDI. In this sense, the results of the study shows that FDI is significantly related to Corruption but there emerged an opposite decision for India and China in terms of parameter. For India, the sign of parameter suggests that corruption negatively affects the FDI while for China it is just the contrary, that is, there is a positive impact of Corruption on FDI. This shows evidence from India and China for presence of both types of relationship between Corruption and FDI. However, the inference is that Corruption and FDI have different relationship in different countries.

\section{References}

Boatright, J. (2000). Ethics and the Conduct of Business. Third Edition. New Jersey: Prentice Hall.

Buckley, P. J., \& Casson, M. (1976). The Future of the Multinational Enterprise. MacMillan Press, London.

Busse, L., Noboru, I., Morgan, M., David, P., Kenneth, S., \& Tolga, Y. (1996). The Perception of Corruption: A Market Discipline Approach. Working Paper, Emory University, Atlanta, GA.

Drabek, Z., \& Payne, W. (1999). The Impact of Transparency on Foreign Direct Investment. Staff Working Paper ERAD-99-02, Geneva, World Trade Organization.

Dunning, J. H. (1977). Trade location of economic activity and the MNE: A search of an eclectic approach, in B. Ohlin, P.O. Hesselborn and P.J. Wijkman (eds.), The International Allocation of Economic Activity. Macmillan, London.

Dunning, J. H. (1988). The eclectic paradigm of international production: A restatement and some possible extensions. Journal of International Business Studies, (19), 1.

Habib, M., \& Zurawicki, L. (2002). Corruption and Foreign Direct Investment. Journal of International Business Studies, 33 (2), 291-307.

Hines, J. (1995). Forbidden Payments: Foreign Bribery and American Business After 1977. Working Paper 5266, National Bureau of Economic Research, Cambridge.

Hymer, S. H. (1960). The International Operations of National Firms: A Study of Direct Foreign Investment. PhD Dissertation. Published posthumously. The MIT Press, 1976. Cambridge, Mass.

Jhingam, M. L. (2008). Money, Banking, International Trade and Public Finance. Delhi, DL: Vrinda Publications (P) Ltd.

Kindleberger, C. P. (1969). American Business Abroad. Yale University Press, New Haven, CT, United States.

Malta Conference. (1994). Report of the Netherlands Ministry of Justice. Proceedings of the 19th Conference of the European Ministers of Justice. La Valetta 14-15th of June, 1994. Strasbourg: Council of Europe Publishing.

Sen, P. (1995). Foreign Direct Investment: A Solution to BOP Problems? Economic and Political Weekly, 30 (30).

Tanzi, V. (1998). Corruption Around the World: Causes, Consequences, Scope, and Cures. IMF Working Paper WP/98/63, International Monetary Fund, Washington, D.C.

Vernon, R. (1966). International Investment and International Trade in the Product Cycle. The Quarterly Journal 
of Economics, 80 (2), 190-207. DOI: 10.2307/1880689

Wei, S. (2000). How Taxing is Corruption on International Investors? The Review of Economics and Statistics, 82(4), 1-12.

Wheeler, D., \& Mody, A. (1992). International Investment Location Decisions: The Case of U.S. Firms. Journal of International Economics, 33, 57-76.

World Bank. (1996). World Debt Tables: External Finance for Developing Countries. Vol. 1 (Analysis and Summary Tables). Washington, D. C.

\section{Annexure I: Variable Description}

\begin{tabular}{|l|l|c|}
\hline Name & Description & Symbol \\
\hline $\begin{array}{l}\text { Corruption } \\
\begin{array}{l}\text { Perception Index } \\
\text { for India }\end{array}\end{array}$ & $\begin{array}{l}\text { Measured on the scale of 10 or 100 represented in the study at a uniform scale } \\
\text { of 10. A 0 score denoted full corruption while a 10 score denoted no corruption. } \\
\text { The data is taken from Transparency International for the period between 1995 } \\
\text { to 2015. }\end{array}$ & CPI \\
\hline $\begin{array}{l}\text { Corruption } \\
\begin{array}{l}\text { Perception Index } \\
\text { for China }\end{array}\end{array}$ & $\begin{array}{l}\text { Measured on the scale of 10 or 100 represented in the study at a uniform scale } \\
\text { of 10. A 0 score denoted full corruption while a 10 score denoted no corruption. } \\
\text { The data is taken from Transparency International for the period between 1995 } \\
\text { to 2015. }\end{array}$ & CPIC \\
\hline $\begin{array}{l}\text { Foreign Direct } \\
\text { Investment Inflows } \\
\text { in India }\end{array}$ & $\begin{array}{l}\text { Expressed as a percentage of GDP. The data is taken form UNCTAD for the } \\
\text { period 1995 to 2014. }\end{array}$ & FDI \\
\hline $\begin{array}{l}\text { Foreign Direct } \\
\text { Investment Inflows } \\
\text { in China }\end{array}$ & $\begin{array}{l}\text { Expressed as a percentage of GDP. The data is taken form UNCTAD for the } \\
\text { period 1995 to 2014. }\end{array}$ & FDIC \\
\hline
\end{tabular}

Source: Prepared by the author

\section{Annexure II: Data Set}

\begin{tabular}{|c|c|c|c|c|}
\hline Year & CPI & FDI & CPIC & FDIC \\
\hline 1995 & 2.78 & 0.582548 & 2.16 & 4.956738 \\
\hline 1996 & 2.63 & 0.648819 & 2.43 & 4.677676 \\
\hline 1997 & 2.75 & 0.856421 & 2.88 & 4.594409 \\
\hline 1998 & 2.90 & 0.619131 & 3.50 & 4.349674 \\
\hline 1999 & 2.90 & 0.478189 & 3.40 & 3.662753 \\
\hline 2000 & 2.80 & 0.767012 & 3.10 & 3.413277 \\
\hline 2001 & 2.70 & 1.134162 & 3.50 & 3.558802 \\
\hline 2002 & 2.70 & 1.114905 & 3.50 & 3.623558 \\
\hline 2003 & 2.80 & 0.730736 & 3.40 & 3.241705 \\
\hline 2004 & 2.80 & 0.807566 & 3.40 & 3.117750 \\
\hline 2005 & 2.90 & 0.910063 & 3.20 & 3.165654 \\
\hline 2006 & 3.30 & 2.144478 & 3.30 & 2.603305 \\
\hline 2007 & 3.50 & 2.101789 & 3.50 & 2.383311 \\
\hline 2008 & 3.40 & 3.639745 & 3.60 & 2.381909 \\
\hline 2009 & 3.40 & 2.662730 & 3.60 & 1.860754 \\
\hline 2010 & 3.30 & 1.608233 & 3.50 & 1.928372 \\
\hline 2011 & 3.10 & 1.874670 & 3.60 & 1.695071 \\
\hline 2012 & 3.60 & 1.278472 & 3.90 & 1.471302 \\
\hline 2013 & 3.60 & 1.455232 & 4.00 & 1.349616 \\
\hline 2014 & 3.80 & 1.686200 & 3.60 & 1.276489 \\
\hline
\end{tabular}

Source: UNCTAD Statistics Database \&Transparency International 
Annexure III: Actual, Fitted and residual Graph for India and China

Chins

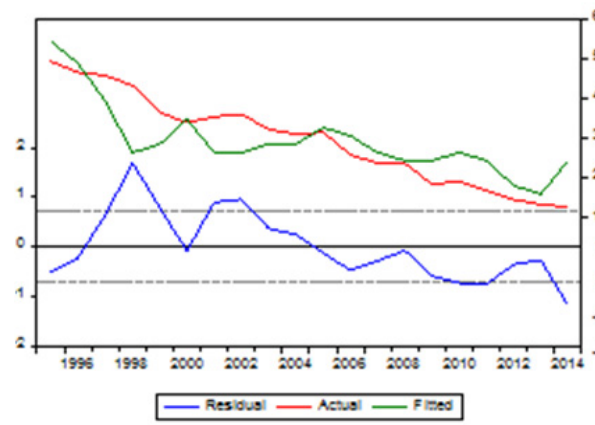

ind a

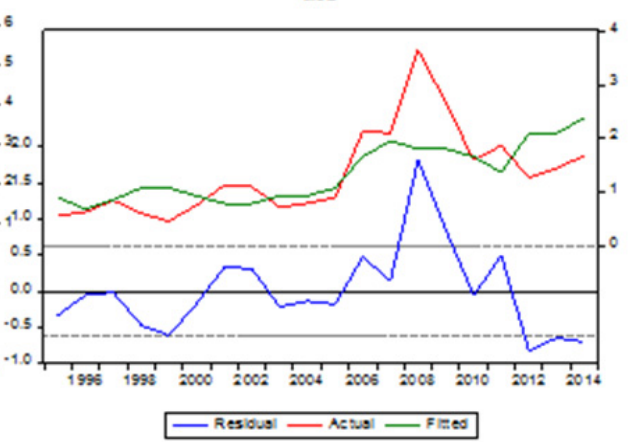

